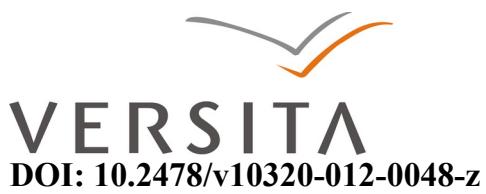

\title{
CONTAINING OTHERNESS THROUGH RATIONAL DETECTION: FEMININE CHARACTERS IN ARTHUR CONAN DOYLE
}

\author{
ELENA MARIA EMANDI \\ "Ştefan cel Mare" University, Suceava, \\ 13 Universității Street, 720229, Suceava, Romania \\ maria_emondi@yahoo.com
}

\begin{abstract}
The present paper is intended to focus on the feminine characters in The Hound of the Baskervilles and The Sussex Vampire. Starting from the analysis of imagery in these two texts I shall exemplify traits of the complex process of encoding otherness.
\end{abstract}

Key words: irrational, other, patriarchy, rational, vampire

Arthur Conan Doyle is considered by many scholars just a marginal writer of Victorian literature, dealing with a sub-literary genre, the detective story. Still, detective stories attract people all over the world, and one of the classics is Sherlock Holmes's series. Jaqueline Jaffe viewed Conan Doyle as "one of the few remaining Victorian writers who has not been 'rediscovered' by contemporary critics" (Clausson 2005:4). Taking into consideration the fact that imperialism and the woman question are key elements in the cultural complex of ideas that define late-Victorian England, I intend to broach a revaluation of Conan Doyle by approaching the feminine characters in two of his writings: The Hound of the Baskervilles and The Sussex Vampire. They share the metaphor of the vampire in feminine guise, either covertly (in the former - at a symbolical level, of course) or overtly (in the latter). They are overcoded with otherness through rational detection. Like Bram Stoker whose England is a land in love with modern science and technology, Arthur Conan Doyle' detective fiction illustrates his preoccupation with the tension between rational deduction and the presence of the 
irrational. Conan Doyle's "othering" of the foreign and of the female "is evident in his construction of character traits and placement of subjects in plot positions" (Favor 2000:398); his fiction also underscores the superiority of the English versus the Other and of the male over the feminine "other".

In both The Hound of the Baskervilles and The Adventures of the Sussex Vampire, the detective has to solve a case that strikes the common reader as being out of the ordinary. The troubling elements are represented by a vampire and a terrible demonic hound. A character in itself, nature (the moor) is more than part of the setting: it is a covert vampire figure that shelters the demonic hound. The Gothic connotations of the setting emphasize the suspense: "behind the peaceful and sunlit countryside there rose ever, dark against the evening sky, the long gloomy curve of the moor, broken by the jagged and sinister hills." (Doyle 2004:72). The violent character of the landscape is suggested by means of sound symbolism: violent consonants suggesting wilderness alternate with gloom-suggestive vowels:

Our wagonette had topped a rise and in front of us rose the huge expanse of the moor, mottled with gnarled and craggy cairns and tors. A cold wind swept down from it and set us shivering. Somewhere there, on that desolate plain, was lurking this fiendish man, hiding in a burrow like a wild beast, his heart full of malignancy against the whole race which had cast him out. It needed but this complete grim suggestiveness of the barren waste, the chilling wind and the darkling sky. (Doyle 2004:73, 74).

The elements containing the semantic trait [+Evil] accompany the description of the desolate unfriendly moor: fiendish man, heart full of malignancy, wild beast. One could even sense the moor as having something criminal in it as long as it shelters such a man. Both the untamed nature in The Hound of the Baskervilles and Mrs. Ferguson in The Adventures of the Sussex Vampire share this criminal feature, somehow speaking about the "New Woman Criminal". This type of woman represents a "specifically public form of femininity for a culture that was redefining and redistricting 'public' and 'private' amid modern social change." (Miller 2008:4) As opposed to real female criminals of the time, these new criminal women indicate that this type of woman was a figure of fantasy rather than a reproduction of the headlines of the epoch. She was not a realistic representation subject in her society, but "an imaginative creation within a wildly 
expanding culture of crime narrative." (Miller 2008: 5). Critics such as Elaine Showalter have underlined the connection between the intense feminist social reform and such new representations of criminality. One can describe this new type of woman as controversial since in a culture so much concerned with detectives and police, she seems to represent "not the new circumscriptions of modern society, but its new freedoms." (Miller 2008:5).

One could not but remark that the rational urban Holmes, whose actions are in support of social order, appears in contrast with the chaotic disorder and uncontrollable force of the moor. Taking into consideration Geoffrey Hartman's assertion according to which "the mystery story has always been a genre in which appalling facts are made to fit into a rational or realistic pattern" (Clausson 2005:5) this opposition between good and evil is necessary since the literary construction of the sublime in Conan Doyle and in any other Gothic atmosphere texts is a space that generates danger, terror and death. Nature, a feminine character, appears in strict connection with the devilish hound. Therefore, it possesses gloomy features:

Beyond, two copses of trees moaned and swung in a rising wind. A half moon broke through the rifts of racing clouds. In its cold night I saw beyond the trees a broken fringe of rocks, and the

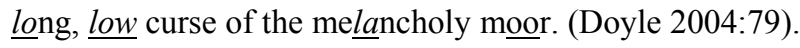

This passage brings to the reader's mind another "melancholy" atmosphere text the one written by Edgar Allan Poe. Sound symbolism suggests a gloomy background: the alternation of vowels and diphthongs creating a low musicality on the one hand and of consonants suggesting the violence of the surroundings culminate in the Poesque alliteration long, low curse of the melancholy moor. The fertile country is presented in contrast with the barren land:

We had left the fertile country behind beneath us [...] The road in front of us grew bleaker [+Unease] and wilder [+Strange] over huge russet and olive slopes, sprinkled with giant boulders. Now and then we passed a moorland cottage, walled and roofed with stone, with no creeper [+Dullness] to break its harsh outline[+Dullness]. (Doyle 2004:74) 
Such surroundings contain something ominous in them, foretelling terrible experiences. An oxymoronic presence, the moor is gloomy and extraordinary at the same time. One could say it has mesmeric forces:

'It's a wonderful place, the moor, said he, looking round over the undulating downs, long green rollers, with crests of jagged granite foaming up into fantastic surges. 'You never tire of the moor. You cannot think the wonderful secrets which it contains. It is so vast, and so barren, and so mysterious.' (Doyle 2004:86)

The duplicitous nature of the bog's surface feeds on everything that traverses it and generates legends. The covert female vampire generates uneasiness in the beholder, linguistically rendered as follows:

What would Holmes say to this? How about that hour of darkness in which the power of evil is exalted? As if in answer to his words there rose suddenly out of the vast gloom of the moor [+Dread] that strange cry [Mystery] which I had already heard upon the borders of the great Grimpen Mire. It came with the wind through the silence of the night, a long, deep mutter [+Gloom] then a rising howl, and then the sad moan [+Gloom] in which it died away. Again and again it sounded, the whole air throbbing with it, strident, wild and menacing. The baronet caught my sleeve and his face glimmered white through the darkness [+Dread]. My blood ran cold in my veins [+Dread], for there was a break in his voice which told of the sudden horror [+Dread] which had seized him. (Doyle 2004:121)

Doyle uses a significant variety of stylistic means to convey the strangeness and dread created by the moor: epithets (vast gloom, strange cry long, deep mutter, rising howl, sad moan, sudden horror), sound symbolism (vast gloom of the moor, strange cry, great Grimpen Mire, long, deep mutter, rising howl, sad moan), accumulation (It came with the wind [...] then a [...] and then [...]; Again and again it sounded, the whole air throbbing with it, strident, wild and menacing), metonymy (effect for cause: his face glimmered white through the darkness), metaphor (my blood ran cold in my veins). An unsettling presence, the moor denies the much craved sanity of family and society at a broader level.

The suspected vampire (in The Adventures of the Sussex Vampire) threatens the idealist Victorian middle-class domestic harmony and so does the difficult-to- tame 
wilderness that houses the terrible hound. In a certain way, both Mrs. Ferguson and the gloomy moor behave like vampires: they are overcoded with otherness through rational detection. Unstable grounds operate as equivocal forces and they are therefore connoted as treacherous and fearful. They generate a dangerous attraction and are construed in the feminine gender. Very much like vampire monsters, the treacherous grounds in The Hound of the Baskervilles mask "a latent instability that physically and psychologically threatens those who seek to transgress their boundaries" (Wyne 2002:77). They create simultaneously fascination and fear: the moor that protects the hound can be viewed as a covert vampire, a female presence that absorbs secrets and propagates legends:

The melancholy of the moon, the death of the unfortunate pony, the weird sound which had been associated with the grim legend of the Baskervilles, all these things tinged my thoughts with sadness. (Doyle 2004: 93).

The same feelings of unease and awe are created by the unexpected behaviour of a Peruvian mother - "The lady began to show some curious traits, quite alien to her ordinary sweet and gentle disposition" (Doyle 1994:72). As the reader might expect, Holmes's reaction to the suspicion of vampirism positions as representative of the patriarchal world governed by reason and logical explanation:

\footnotetext{
'Rubbish, Watson, rubbish! What have we to do with walking corpses who can only be held in their grave by stakes driven through their hearts? It's pure lunacy.'

'But surely,' said I, 'the vampire was not necessarily a dead man? A living person might have the habit. I have read for example, of the old sucking the blood of the young in order to retain their youth.'

'You are right, Watson. It mentions the legend in one of these references. But are we to give serious attention to such things? This agency stands flat-footed upon the ground, and there it must remain. The world is big enough for us. No ghosts need apply.'
}

As in the case of the dangerous hound sheltered in the gloomy moor, feminine sexuality in the second vampire story is an element that must be controlled in order for rationality and realism to prevail. The work done by Holmes and Watson is meant to keep at bay the threat of the independent, sexual Woman. Holmes proves successful in his goal 
of defending Victorian values. He therefore dispels the threat of the demonic hound (living in an ill-omened environment symbolically associated with a vampire) and of vampirism (that can be interpreted as a metaphor for feminine sexuality). An aspect that is worth mentioning is the emphasis on Mrs. Ferguson's role of devoted wife and mother at the expense of her sexuality and independence. After all, through her silence she proves to be a self-effacing type of woman. She conforms to the general pattern of sheepish obedience like other women in Doyle's writing: Miss Stapleton or Mrs. Laura Lyons.

Mrs. Ferguson and her story provide a space for the exploration of otherness: she is suspected to be a vampire, therefore she is otherized. She is also non-English. Her vampirism, sign of her sexual nature, represents a threat to her family. Mrs. Ferguson and the mire represent the female evil festering within a patriarchal structure that creates anxiety about the female body and its threatening claims to prestige and power. Going one step further, one may understand the tension emerging between rational deduction and the presence of the irrational suggestive in their turn of the tension between romance and realism, as Cyndy Hendershot (1996:10) states in "The Restoration of the Angel: Female Vampirism in Doyle's The Adventures of the Sussex Vampire". She views Holmes as a representative of bourgeois realism working on a case involving Gothic romance figures such as the vampire or the demonic hound, we might add. The vampire cast as the wayward woman failing to live up to Victorian virtue. As a consequence, she becomes chaotic and eventually, evil. Christin Leon Alfar (2003:32) speaks about a spectralization of the female identity as women turn, figuratively, into spectres haunting a masculinist order. For Jacques Derrida the spectre is "among other things, what one imagines, what one thinks or sees and which one projects - on an imaginary screen where there is nothing to see" (Alfar 2003:32). The feminine characters appear as embodiments of this need to stabilize which is inherently and irrevocably insecure.

This paper is an attempt at revaluating Arthur Conan Doyle - an important if not major Victorian writer, and its main aim is to exemplify the pattern followed by the detective stories as far as the relationship between the presence of the irrational and the immediate rational is concerned, where the irrational stands for other/ non-English and its rational counterpart stands for male / English. 
The feminine characters that appear as embodiments of female vampires/ other in the two works analysed are controlled through Holmes's rational actions, drawing the reader's attention towards an essential aspect: the difference between male vampires and female vampires consists in the fact that while both of them break social and sexual taboos, it is "the female vampire in Victorian examples of the genre that crystallizes Victorian fears." (Hamilton 2004:4). In other words we come across the complex encoding of the tensions between the masculine norm and the feminine other, "between the rational world of the detective and the Gothic romance world of the vampire." (Hendershot 1996:13). The recontainment of Mrs. Ferguson and the explanation found in the case of the demonic hound threatening the Baskervilles fit the pattern outlined above, Holmes succeeding in his effort of defending the Victorian home and the the status quo.

\section{References}

Alfar, C. L. 2003. Fantasies of Female Evil: The Dynamics of Gender and Power in Shakespearean Tragedy. Newark: University of Delaware Press.

Clausson, N. 'The Case of the Anormalous Narrative: Gothic "Surmise" and

Trigonometric "Proof" in Arthur Conan Doyle's The Musgrave Ritual' in Victorian Newsletter. Spring 2005, Issue 107.

Doyle, A. C. 1994. The Case-Book of Sherlock Holmes. W. W. Robson (ed.). Oxford: Oxford University Press.

Doyle, A. C. 1915. The Hound of the Baskervilles. London: CRW Publishing Limited.

Favor, L. J. 2000. 'The Foreign and the Female in Arthur Conan Doyle: Beneath the Candy Coating' in English Literature in Transition 1880-1920, Vol. 43, Issue 4.

Hamilton, R. P. 2004. This Thing of Darkness. Perspectives on Evil and Human

Wickedness. Amsterdam: Rodopi.

Hendershot, C. 1996. 'The Restoration of the Angel: Female Vampirism in Doyle's The Adventures of the Sussex Vampire' in Victorian Newsletter. Spring 1996. Issue 89.

Miller, E. C. 2008. Framed: The New Woman Criminal in British Culture at the Fin de Siècle, Michigan: University of Michigan Press and University of Michigan Library.

Wyne, C. 2002. The Colonial Conan Doyle: British Imperialism, Irish Nationalism, and the Gothic. Westport: Greenwood Press. 